\title{
UNDOING BABEL
}

The Tower of Babel in Anglo-Saxon Literature 
This page intentionally left blank 


\section{Undoing Babel}

The Tower of Babel in Anglo-Saxon Literature

TRISTAN MAJOR 
(C) University of Toronto Press 2018

Toronto Buffalo London

www.utorontopress.com

Printed in the U.S.A.

ISBN 978-1-4875-0054-2 (cloth)

$\infty$

Printed on acid-free, $100 \%$ post-consumer recycled paper with vegetable-based inks.

\section{Library and Archives Canada Cataloguing in Publication}

Major, Tristan, author

Undoing Babel : the Tower of Babel in Anglo-Saxon literature / Tristan Major.

(Toronto Anglo-Saxon series)

Includes bibliographical references and index.

ISBN 978-1-4875-0054-2 (hardcover)

1. English literature - Old English, ca. 450-1100 - History and criticism.

2. Babel, Tower of, in literature. I. Title.
PR173.M35 2018
$829^{\prime} .09372$
C2017-904464-8

This book has been published with the help of a grant from the Federation for the Humanities and Social Sciences, through the Awards to Scholarly Publications Program, using funds provided by the Social Sciences and Humanities Research Council of Canada.

University of Toronto Press acknowledges the financial assistance to its publishing program of the Canada Council for the Arts and the Ontario Arts Council, an agency of the Government of Ontario.

Canada Council for the Arts
Conseil des Arts du Canada
ONTARIO ARTS COUNCIL

CONSEIL DES ARTS DE L'ONTARIO

an Ontario government agency

un organisme du gouvernement de I'Ontario $\begin{array}{rr}\begin{array}{r}\text { Funded by the } \\ \text { Government } \\ \text { of Canada }\end{array} & \begin{array}{r}\text { Financé par le } \\ \text { du Canementa }\end{array}\end{array}$ 
To Zoe 
This page intentionally left blank 